\title{
DETERMINATION OF FLAVONOIDS IN CITRUS FIBER AND THE IMPACT OF PROCESSING METHOD ON TOTAL PHENOLIC CONTENT, TOTAL FLAVONOID CONTENT, TOTAL CAROTENOID CONTENT AND OXYGEN RADICAL ABSORBANCE CAPACITY
}

\author{
Ayça Gedikoğlu*1, Andrew Douglas Clarke², Ingolf Gruen² \\ ${ }^{1}$ Konya Food and Agriculture University, Department of Food Engineering, Konya, Turkey \\ ${ }^{2}$ Department of Food Science, University of Missouri, USA
}

Received /Geliş: 11.07.2018; Accepted / Kabul: 15.10.2018; Published online /Online bask1: 03.11.2018

Gedikoğlu, A., Clarke, A. D., Gruen, I. (2018). Determination of flavonoids in citrus fiber and the impact of processing method on total phenolic content, total flavonoid content, total carotenoid content and oxygen radical absorbance capacity. GID $A$ (2018) 43 (6): $917-924$ doi: 10.15237/gida.GD18072

Gedikoğlu, A., Clarke, A. D., Gruen, I. (2018). Turunçgil lifinde flavonoidlerin belirlenmesi ve üretim metodunun toplam fenolik miktarı, toplam flavonoid miktarı, toplam karotenoit miktarı ve oksijen radikal soğurma kapasitesine etkisi. GIDA (2018) 43 (6): 917-924 doi: 10.15237/gida.GD18072

\begin{abstract}
The objective of this study is to evaluate the presence of flavonoids in citrus fiber using reverse-phase highpressure liquid chromatography (RP-HPLC). In this study, we also investigate the effect of regular and hotwashing preparations on total polyphenol content (TPC), total flavonoid content (TFC), oxygen radical absorbance capacity (ORAC) and total carotenoid content (TCC) of citrus fiber. The HPLC method used provided fast results and good separation for polymethoxyflavones and flavonols. Quercetin and kaempferol (flavonols), and sinensetin, nobiletin, heptamethoxyflavone, and tangeretin (polymethoxyflavones) were identified. Nobiletin had the highest concentration with $3.33 \mathrm{mg} / \mathrm{g}$ dry weight followed by sinensetin $(1.96 \mathrm{mg} / \mathrm{g}$ dry weight) and heptamethoxyflavone $(1.24 \mathrm{mg} / \mathrm{g}$ dry weight), respectively. The TFC and TCC of citrus fiber were unaffected $(P>0.05)$ by the citrus fiber production procedure; however, the TPC and the ORAC values of citrus fiber prepared using hot-washing were significantly lower $(P<0.05)$.
\end{abstract}

Keywords: Citrus, fiber, flavonoid, total polyphenol content, ORAC value, HPLC

\section{TURUNÇGİL LIFİNDE FLAVONOİDLERİN BELİRLENMESİ VE ÜRETİM METODUNUN TOPLAM FENOLIK MİKTARI, TOPLAM FLAVONOİD MİKTARI, TOPLAM KAROTENOİT MÍKTARI VE OKSİJEN RADİKAL SOĞURMA KAPASİTESİNE ETKİSİ}

\section{ÖZ}

Bu çalışmanın amacı turunçgil kabuğundan elde edilen liflerin ters fazlı yüksek basınçlı sıvı kromatografisi yöntemi ile flavonoidlerinin belirlenmesidir. Ayrıca, bu çalışmada turunçgil kabuklarından lif hazırlanırken kullanılan normal veya sıcak yıkama işlemlerinin toplam fenol miktarı, toplam flavonoid miktarı, toplam karotenoid miktarı ve oksijen radikal soğurma kapasitesi değerine etkisi araştırılmaktadır. Kullanılan HPLC metodu çoklu metoksiflavon ve flavanollerin ayrılmasını sağlayan ve hızlı sonuç veren bir yöntemdir. Kuersetin, kemferol, sinensetin, nobiletin, heptamethoksiflavon ve tangeretin belirlenmiştir. Nobiletin $3.33 \mathrm{mg} / \mathrm{g}$ kuru ağırlık ile en yüksek miktarda bulunan flavonoiddir. Sinensetin $1.96 \mathrm{mg} / \mathrm{g}$ kuru ağırlık ile, heptametoksiflavon ise $1.24 \mathrm{mg} / \mathrm{g}$ kuru ağırlık ile takip etmektedir. Sicak yıkama veya normal yıkamanın toplam flavonoid içeriği ve toplam karotenoid içeriğine etkisi görülmemiştir $(P>0.05)$. Ancak, toplam fenolik madde ve oksijen radikal soğurma kapasitesi değeri sıcak yıkama yapılan liflerde daha düşük bulunmuştur $(P<0.05)$.

Anahtar kelimeler: Turunçgil, lif, flavonoid, toplam fenol miktarı, oksijen radikal soğurma kapasitesi değeri, HPLC

* Corresponding author / Yazışmalardan sorumlu yazar;

$\square$ ayca.gedikoglu@gidatarim.edu.tr, $\quad(0(+90) 3322235450$

岛(+90) 3322235490 


\section{INTRODUCTION}

Citrus fruit production takes places mostly in tropical and sub-tropical areas in the world. Main citrus fruits are oranges, grapefruit, lemon, tangelos, tangerines and mandarins. According to a U. S. Department of Agriculture (2013) report approximately $35.5 \%$ of the citrus fruits are consumed as fresh fruit while the rest has been processed into juice. Using the majority of the citrus fruits for juice production creates a large amount of waste. The waste products from the peel and seeds are prone to microbial spoilage, making this waste material a candidate for use mostly as animal feed and fertilizer (FernandezLopez et al., 2004). However, it has been reported by Saura-Calixto (1998) and Larrauri (1999) that fruit by-products, such as peels, are rich in dietary fiber. Also, due to the presence of flavonoids and carotenoids, they have better nutritional quality than fiber from cereals, as well as a balanced composition of soluble and insoluble fiber and low energy values. Also, Gorinstein et al. (2001) and Fernandez-Lopez et al. (2004) stated that citrus by-products, such as peel (albedo and flavedo), are not only rich in fiber, but due to the presence of phenolic compounds and antioxidants, such as ascorbic acid, they can be used in food products to provide further functional benefits. Lario et al. (2004) stated that fruit fibers, such as citrus, provide good quality soluble and insoluble fiber, as well as functional properties, such as water- and oil-holding capacity. Gorinstein et al. (2001) found that the peels of oranges, lemons, and grapefruits had higher total dietary fiber, soluble fiber, and insoluble fiber than these fruits without peel, on both fresh and dry weight bases. Besides these possible functional advantages, citrus fiber can provide health benefits. It has been reported that consuming a fiber-rich diet is associated with decreased incidence of atherosclerosis, hemorrhoids, and colon cancer (Rodriguez et al., 2006). Additionally, the antioxidant potential due to the presence of flavonoids, flavonols and polymethoxyflavones (PMFs) in citrus peel contributes functional and health benefits (Manthey and Grohmann, 1996; Bocco et al., 1998; Gorinstein et al., 2001). In most of those investigations, the citrus peels obtained for the experiments were fresh rather than processed and no study has investigated the presence of these flavonoids in mass-produced citrus by-products.

Therefore, the objective of this research was to provide information about the identity and quantity of flavonoids found in mass-produced citrus fiber by reverse-phase HPLC and provide information on the effect of two types of processing procedures (regular washing and hot washing of peels) of citrus fiber on the TPC, TFC, TCC, and the antioxidant potential of such powder.

\section{MATERIALS AND METHODS}

\section{Materials}

Folin-Ciocalteu's phenol reagent was obtained from MP Biomedicals (Santa Ana, Calif., U.S.A.). Aluminum chloride anhydrous $\left(\mathrm{AlCl}_{3}\right)$, potassium acetate $\left(\mathrm{CH}_{3} \mathrm{COOK}\right)$, sodium carbonate $\left(\mathrm{Na}_{2} \mathrm{CO}_{3}\right)$, HPLC-grade water, HPLC-grade acetonitrile, HPLC-grade methanol, and glacial $\mathrm{m}$-phosphoric acid were obtained from Fisher Scientific (Waltham, Mass., U.S.A.). Quercetin, kaempferol, and $\beta$-carotenoid were obtained ( $95 \%$ > purity by HPLC) from Sigma-Aldrich ${ }^{\circledR}$ Co. (St. Louis, Mo., U.S.A.). Gallic acid was obtained from Fluka ${ }^{\circledR}$ Analytical (St. Louis, Mo., U.S.A.). An ORAC antioxidant assay kit was obtained from Zen-Bio, Inc. (Research Triangle Park, N.C., U.S.A.). Nobiletin, sinensetin, tangeretin, and heptamethoxyflavone were kindly provided by Dr. John Manthey, U.S. Horticultural Research Laboratory, United States Department of Agriculture (USDA), Fort Pierce, Florida.

\section{Citrus Fiber}

Sources of the fiber used in this study are albedo and flavedo parts of the orange peel. CitraFiber ${ }^{\mathrm{TM}}$ products were kindly provided by Natural Citrus Products Corporation (Fort Pierce, Fla., U.S.A). Since the CitraFiber ${ }^{\mathrm{TM}}$ is a patented, commercially mass produced product, hot and cold wash procedures were done by the company. Products were fine ground in powder form. Nutrition profile of the both citrus fibers were same and can be seen in Table 1. 
Table 1. Nutritional facts about citrus fiber CitraFiber ${ }^{\mathrm{TM}}$

\begin{tabular}{lc}
\hline Total Pectin & $9390 \mathrm{mg} / 100 \mathrm{~g}$ \\
Protein & $6.37 \%$ \\
Total Sugars & $1.7 \%$ \\
Total Dietary Fiber & $82.7 \%$ \\
Soluble Fiber & $23.4 \%$ \\
Insoluble Fiber & $59.3 \%$ \\
Potassium & $453 \mathrm{mg} / 100 \mathrm{~g}$ \\
Sodium & $210 \mathrm{mg} / 100 \mathrm{~g}$ \\
Calcium & $78 \mathrm{mg} / 100 \mathrm{~g}$ \\
Vitamin A (Beta Carotene) & $117 \mathrm{IU} / 100 \mathrm{~g}$ \\
Vitamin C & $0.91 \mathrm{mg} / 100 \mathrm{~g}$ \\
\hline Source: Natural Citrus Products
\end{tabular}

\section{Standard Preparation}

Stock solutions of quercetin $(50 \mu \mathrm{g} / \mathrm{mL})$, kaempferol $(120 \mu \mathrm{g} / \mathrm{mL})$, sinensetin $(1060 \mu \mathrm{g} /$ $\mathrm{mL})$, nobiletin (540 $\mu \mathrm{g} / \mathrm{mL})$, heptamethoxyflavone $(1900 \mu \mathrm{g} / \mathrm{mL})$, and tangeretin $(820 \mu \mathrm{g} / \mathrm{mL})$ were prepared by dissolving these compounds individually in HPLC-grade methanol. The proper amounts of each standard and cocktail of standards were made by taking appropriate amounts from each standard and filtering them with a $0.45 \mu \mathrm{m}$ filter before using them for the HPLC procedure.

\section{Aqueous Acetone Extraction}

The methodology of Rodriguez-Saona and Wrolstad (2001) was used with modifications for this study. Ten $g$ of sample was weighed into a beaker. Then, $40 \mathrm{~mL}$ of acetone (1:4 ratio of $\mathrm{w} / \mathrm{v})$ was measured and placed into the beaker and blended. Using a Buchner funnel, vacuum flask, and Whatman ${ }^{\circledR}$ no. 1 filter paper, the slurry was filtered. While keeping the filtered solution in the dark and under refrigeration, the filtered slurry was placed in a beaker, and $40 \mathrm{~mL}$ of $70 / 30(\mathrm{v} / \mathrm{v})$ acetone/acidified $(0.01 \% \mathrm{HCl})$ water solution was added. After sonicating for one hour, the slurry was filtered again with a Buchner funnel, vacuum flask, and Whatman ${ }^{\circledR}$ no. 1 filter paper. This procedure was repeated two more times until a faint yellow color was observed. The collected filtrates were combined, and the liquid extract was placed into a $300 \mathrm{~mL}$ round-bottom flask. The acetone and water in the extract were completely evaporated using a rotary evaporator at $50{ }^{\circ} \mathrm{C}$. The residue was dissolved in $10 \mathrm{~mL}$ of methanol.
This extract was used for the TPC, TFC, and ORAC values as well as HPLC analysis. The methanol extract was filtered with a $0.45 \mu \mathrm{m}$ filter before being analyzed by HPLC. The extract was kept in the freezer at $-18{ }^{\circ} \mathrm{C}$ during the experiment.

\section{HPLC Analysis}

A Varian ProStar model 410 AutoSampler equipped with Varian 210-218 pumps and a Varian 335 UV detector was used for this study. Separation was achieved by using an Eclipse XDB $\mathrm{C}_{18} 5 \mu \mathrm{m}(4.6 \times 250 \mathrm{~mm})$ column (Agilent Technologies, Santa Clara, Calif., U.S.A.). The mobile phases consisting of $0.1 \%$ phosphoric acid in water (A) and acetonitrile (B) were used in a gradient program as follows: $100 \%$ (A) for the first $3 \mathrm{~min}$, then $45 \%$ (A) for the next $9 \mathrm{~min}$, and finally $5 \%$ (A) for the next $13 \mathrm{~min}$. The mobile phase flow rate was $1 \mathrm{~mL} / \mathrm{min}$. The column temperature was kept at $30{ }^{\circ} \mathrm{C}$. The injection volume was $20 \mu \mathrm{L}$. The chromatographic peaks were identified based on their retention times and compared with the retention times of the authentic standards. Flavonoid levels in the sample were calculated based on the external standard curve of the chosen flavonol and polymethoxyflavones (PMFs) standards.

\section{Determination of Total Polyphenol Content}

To determine TPC, $0.1 \mathrm{~mL}$ of sample extracts were mixed with $2.8 \mathrm{~mL}$ of deionized water, $2 \mathrm{~mL}$ of $2 \%$ sodium carbonate $\left(\mathrm{Na}_{2} \mathrm{CO}_{3}\right)$, and $0.1 \mathrm{~mL}$ of $50 \%$ Folin-Ciocalteu reagent. After the solution was incubated at room temperature for 
30 min, the reaction mixture absorbance was measured at $750 \mathrm{~nm}$. A deionized water blank was used for zeroing the spectrophotometer. Gallic acid was chosen as a standard, and a six-point standard curve was prepared $(0-60 \mathrm{mg} / \mathrm{L})$. The total polyphenol content of the citrus fiber was expressed as gallic acid equivalents ( $\mathrm{mg} \mathrm{GA} / \mathrm{g}$ ) for dry weight (Lin and Tang, 2007).

\section{Determination of Total Flavonoid Content}

To determine TFC, $0.5 \mathrm{~mL}$ sample extracts were mixed with $1.5 \mathrm{~mL}$ of $95 \%$ ethanol, $0.1 \mathrm{~mL}$ of $10 \%$ aluminum chloride $\left(\mathrm{AlCl}_{3}\right), 0.1 \mathrm{~mL}$ of $1 \mathrm{M}$ potassium acetate $\left(\mathrm{CH}_{3} \mathrm{COOK}\right)$, and $2.8 \mathrm{~mL}$ of deionized water. After the solution was incubated at room temperature for $30 \mathrm{~min}$, the reaction mixture absorbance was measured at $415 \mathrm{~nm}$. A deionized water blank was used for zeroing the spectrophotometer. Quercetin was chosen as a standard, and a seven-point standard curve was prepared $(0-100 \mathrm{mg} / \mathrm{L})$. The total flavonoid content of the citrus fiber was expressed as quercetin equivalents (mg QUE/g) for dry weight (Lin and Tang, 2007).

\section{Determination of Total Carotenoid Content}

A slurry of $2.5 \mathrm{~g}$ of citrus fiber and $25 \mathrm{~mL}$ of $\mathrm{n}$ hexane-acetone-ethanol (v/v/v: 50:25:25) was placed on a shaker for $10 \mathrm{~min}$ at $200 \mathrm{rpm}$ at room temperature. Then, it was centrifuged at $4500 \mathrm{~g}$ for $15 \mathrm{~min}$ at $8{ }^{\circ} \mathrm{C}$. The supernatant was collected and made to a volume of $25 \mathrm{~mL}$ with hexane. Absorbance was measured at $450 \mathrm{~nm}$. $\beta$-carotene was chosen as a standard, and a seven-point standard curve was prepared $(0-100 \mathrm{mg} / \mathrm{L})$. The total carotenoid content was expressed as betacarotene equivalents $(\mathrm{mg} \beta-\mathrm{C} / \mathrm{g}$ ) of dry weight. This methodology was adopted from Lee (2001), with some modifications.

\section{Oxygen Radical Absorbance Capacity Assay}

For this study, instructions from the Zen-Bio kit (Zen-Bio, Inc., Research Triangle Park, N.C., U.S.A.) were followed. A 96-well microplate was used for analysis. The plate reader incubation chamber was set to $37^{\circ} \mathrm{C}$ (BioTek ${ }^{\circledR}$ Instruments, Inc., Synergy ${ }^{\mathrm{TM}}$ HT, Winooski, Vt., U.S.A.); excitation wavelength was set to $485 \mathrm{~nm}$; and emission wavelength was set to $530 \mathrm{~nm}$. After preparation of the working solution and standard solutions, $150 \mu \mathrm{L}$ of the working solution was added to each well followed by $25 \mu \mathrm{L}$ of each sample, standard, or blank. Finally, $25 \mu \mathrm{L}$ of the AAPH (2,2'-azobis-2- methyl-propanimidamide, dihydrochloride) solution was added to each well and read over $30 \mathrm{~min}$. Trolox was used as the standard, and a five-point $(0-50 \mu \mathrm{M})$ standard curve was prepared. The ORAC values of the samples were calculated based on Davalos et al. (2004) and were expressed as $\mu$ mole Trolox/g.

\section{Statistical Analysis}

Three replications of citrus fiber were evaluated for the TPC, TFC, TCC, and ORAC values. Data was analyzed by analysis of variance (ANOVA) using the general linear model (GLM) procedure of the SAS ${ }^{\circledR}$ Institute Inc. (2011). Means were separated by least significant difference (LSD) when significant $(P<0.05)$ treatment effects were found.

\section{RESULTS AND DISCUSSION}

Figure 1 shows the chromatogram of regularwashed citrus fiber. There were two groups of flavonoids found in the citrus samples. The first group was flavonols, and the second group was polymethoxyflavones. There was good separation of four major PMFs and flavonols, which eluted after $10 \mathrm{~min}$. While glycosylated flavonones with an elution window of 8-10 min were also detected based on information obtained from running pure standards of glycosylated flavanones (narirutin, hesperidin and isosakuranetinrutinoside), they were insufficiently separated for proper identification or quantitation. The method used in this study provides a fast analysis time for identification of flavonols and PMFs. The quantification of flavonols and polymethoxyflavones were carried out using external standard curves. The results are shown in Table 2 . 


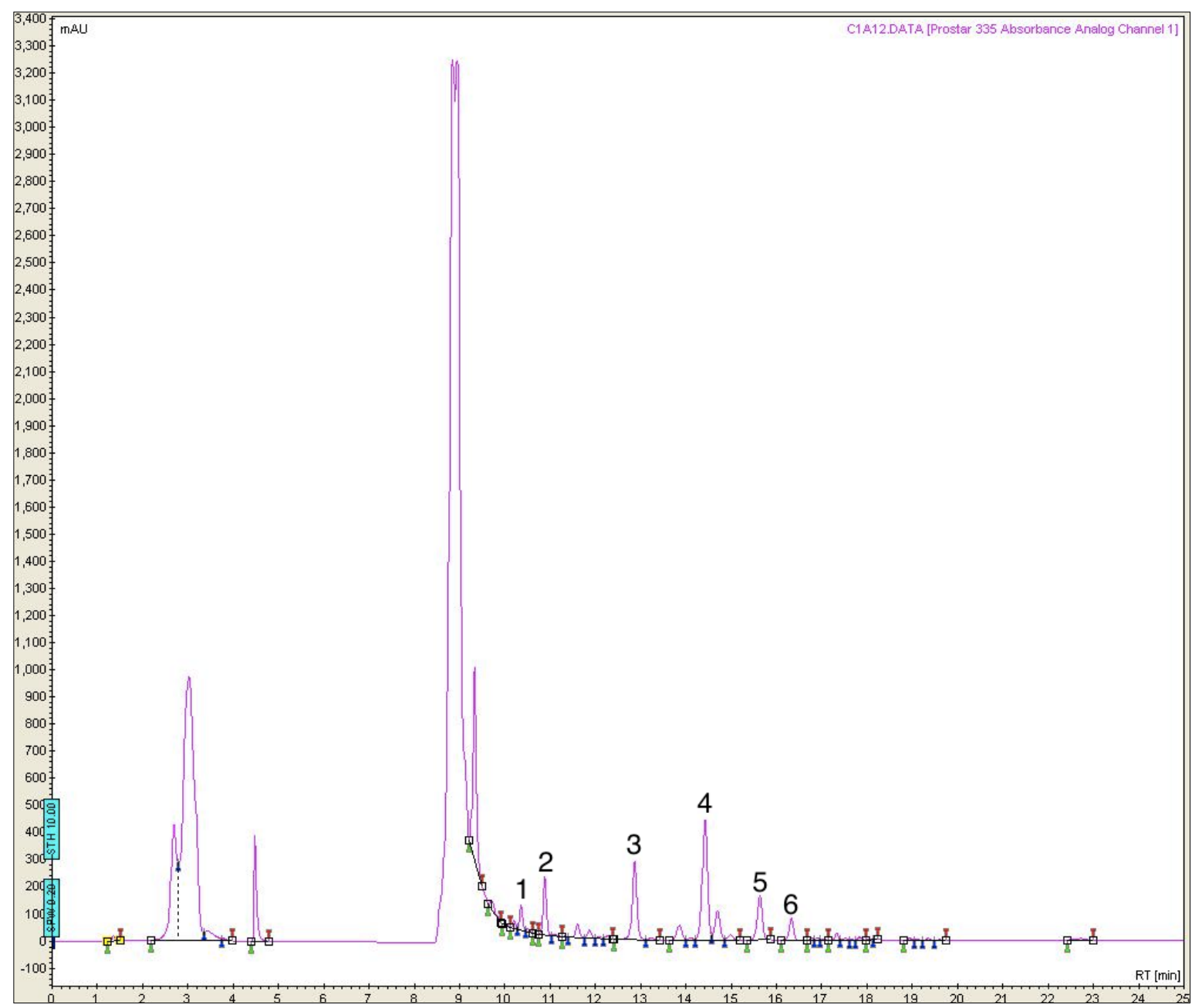

Figure 1. Reverse-Phase HPLC Chromatogram of Flavonols and Polymethoxyflavones Extracted from Regular-Washed Citrus Fiber

Peak identifications: 1 - quercetin (QUE), 2 - kaempferol (KAE), 3 - sinensetin (SIN), 4 - nobiletin (NOB), 5 - heptamethoxyflavone (HMF) and 6 - tangeretin (TAN).

Table 2. Flavonols and Polymethoxylated Flavones Concentration in Regular-Washed Citrus Fiber from Florida

\begin{tabular}{lc}
\hline Compound & Quantity $(\mathrm{mg} / \mathrm{g}, \mathrm{dw})$ \\
\hline Flavonols & $0.0276 \pm 0.0107$ \\
Quercetin & $1.0945 \pm 0.439$ \\
Kaempferol & \\
Polymethoxylated & $1.9608 \pm 0.958$ \\
Flavones & $3.3304 \pm 1.621$ \\
Sinensetin & $1.2155 \pm 0.599$ \\
Nobiletin & $0.5005 \pm 0.251$ \\
Heptamethoxyflavone & \\
Tangeretin & \\
\hline Each value in the Table is represented as mean \pm \\
standard deviation $(\mathrm{n}=3)$.
\end{tabular}

Nobiletin had the highest concentration of all the flavones, followed by sinensetin, then heptamethoxyflavone. Similar results were obtained by Green et al. (2007). They found that Navel orange peels from the Jamaican cultivars had $3.8 \mathrm{mg} / \mathrm{g}$ nobiletin, $3.6 \mathrm{mg} / \mathrm{g}$ sinensetin and $2.6 \mathrm{mg} / \mathrm{g}$ heptamethoxyflavone. They also found that the majority of the Mexican citrus cultivars had nobiletin as the highest PMF in the citrus peels and nobiletin concentration for sweet orange peels type 1 and type 2 were $5.67 \mathrm{mg} / \mathrm{g}$, $3.96 \mathrm{mg} / \mathrm{g}$, respectively. The presence of flavonoids is influenced by the type of cultivar, as well as by the different tissues (albedo, flavedo, 
juice vesicles) of citrus fruits (Nogata et al., 2006). Our findings were within the range of the results reported in earlier studies that focused on the identification and quantification of flavanone glycosides and PMFs (Manthey and Grohmann, 1996; Bocco et al., 1998; Green et al., 2007; Sun et al., 2010). A few studies also found the presence of flavonols, particularly quercetin and kaempferol, in citrus cultivars. Kawaii et al. (1999) found quercetin in trace amounts in Citrus paradisi (grapefruit) juice extract, while kaempferol was found in trace amounts in Citrus aurantium (sour orange) juice extract. Also, Ross et al. (2000); Vanamala et al. (2006) reported the presence of quercetin in commercially available grapefruit juices. Wang et al. (2008) investigated the presence of flavonols in eight citrus species in Taiwan. They found trace amounts of quercetin and kaempferol in the peels of all citrus cultivars. Recently, Shalaby et al. (2011) identified the presence of kaempferol in Citrus aurantifolia (key lime) leaves, while quercetin was identified in both the leaves and peel of Citrus sinensis (sweet orange). Quercetin has shown some antiviral activity (Kaul et al., 1985; Tripoli et al., 2007). Also, it has been reported that polymethoxylated flavones provide antibacterial activity (Tripoli et al., 2007).

Table 3 shows the comparison of citrus fiber type on the presence of the TPC, TFC, TCC, and ORAC values. The results show that the total polyphenol content of citrus fibers significantly $(P$ $<0.05)$ differ between hot-washed and regularwashed citrus fibers. Total polyphenol content, total flavonoid content, total carotenoid content and antioxidant capacity of citrus fruits can be influenced by many factors, such as season, soil quality, altitude, type of cultivar, processing procedure and whether it is a fresh or a dry product. Lutz et al. (2015) reported that total phenolic content and antioxidant capacity of fresh fruits were higher than dry counterpart. Ghasemi et al. (2009) reported similar results for the TFC for 13 cultivars of citrus peel including sweet orange, bitter orange, lemon etc., but they reported much higher total polyphenol contents (90.3-396.8 $\mathrm{mg} \mathrm{GAE} / \mathrm{g}$ ) than our study found. Sankalpa et al. (2017) reported that processing method influenced the TFC, TPC, TCC and radical scavenging activity of sweet orange peel powder. There was no statistical difference $(P$ $>0.05$ ) in the total flavonoid content and the total carotenoid content between hot-washed citrus fibers and regular-washed citrus fiber, which as shown in Table 3. Wang et al. (2008) reported the highest total carotenoid content in Citrus reticulata Blanco (tangerine) peel with $2.04 \pm 0.036 \mathrm{mg} / \mathrm{g}$, while Citrus sinensis L. Osbeck (orange) peel had $0.445 \pm 0.008 \mathrm{mg} / \mathrm{g}$, and Citrus limon L. Bur peel had $0.110 \pm 0.001 \mathrm{mg} / \mathrm{g}$. While TFC and TCC were not affected by the processing method, the ORAC values were affected. Hot-washed samples had lower ORAC values than regular-washed samples. Li et al. (2006) reported that frozen lemon peel made from fresh lemons had significantly higher total polyphenol content than oven-dried lemon peel for dried bases. They suggested that a long drying time or temperature might cause a decrease in the total polyphenol content. Second, the use of hot water for citrus fiber preparation might lead to a reduction in the antioxidant capabilities of some of the polyphenols and flavonoids, resulting in much lower ORAC values.

Table 3. Effect of Extraction Methodology and Type of Citrus Fiber on Total Polyphenol Count, Total Flavonoid Count, and Oxygen Radical Absorbance Capacity of Citrus Fiber

\begin{tabular}{lcccc}
\hline $\begin{array}{l}\text { Citrus } \\
\text { Samples }\end{array}$ & $\begin{array}{c}\text { TPC } \\
(\mathrm{mg} \mathrm{GAE} / \mathrm{g}, \mathrm{dw})\end{array}$ & $\begin{array}{c}\text { TFC } \\
(\mathrm{mg} \text { QUEE} / \mathrm{g}, \mathrm{dw})\end{array}$ & $\begin{array}{c}\text { TCC } \\
(\mathrm{mg} \beta-\mathrm{CE} / \mathrm{g}, \mathrm{dw})\end{array}$ & $\begin{array}{c}\text { ORAC Value } \\
(\mu \text { Mole Trolox } / \mathrm{g}, \mathrm{dw})\end{array}$ \\
\hline C1 & $9.959 \pm 1.31^{\mathrm{a}}$ & $9.621 \pm 0.38$ & $0.176 \pm 0.0060$ & $27.834 \pm 6.86^{\mathrm{a}}$ \\
$\mathrm{C} 2$ & $7.959 \pm 0.79^{\mathrm{b}}$ & $9.413 \pm 0.97$ & $0.168 \pm 0.0095$ & $15.589 \pm 4.53^{\mathrm{b}}$ \\
\hline
\end{tabular}

a,b Different letters in the same column indicate significant difference $(P<0.05)$ analyzed by t-tests (least significant difference).

Each value in the Table is represented as mean \pm standard deviation $(\mathrm{n}=3)$.

C1: represents regular-washed samples.

C2: represents hot-washed sample 


\section{CONCLUSION}

The high-pressure liquid chromatography technique used in this study provided fast results and good separation for polymethoxyflavones and flavonols in citrus fiber. Nobiletin, sinensetin, heptamethoxyflavone, tangeretin, quercetin, and kaempferol were identified. While quercetin was found in trace amounts, polymethoxyflavones were found in much higher quantities in the citrus fiber. Processing, i.e. hot-washing or regularwashing, of citrus fibers did not influence the TFC or the TCC. However, the regular-washed citrus samples had a higher total phenolic content and antioxidant capacity than the hot-washed citrus fibers. Results of our study also indicated that citrus fibers used in this study had relatively lower flavonoid concentration, TPC, TFC and ORAC values than what was found in the literature with fresh citrus peels.

\section{ACKNOWLEDGEMENTS}

We would like to thank Dr. Misha T. Kwasniewski and Gwo Yuh Liu from the Grape and Wine Institute, College of Agriculture, Food and Natural Resources, University of Missouri, for their technical support.

\section{REFERENCES}

Bocco, A., Cuvelier, M-E., Richard, H., Berset, C. (1998). Antioxidant activity and phenolic composition of citrus peel and seed extracts. $J$ Agric Food Chem, 46: 2123-2129.

Davalos, A., Gomez-Cordoves, C., Bartolome, B. (2004). Extending applicability of the oxygen radical absorbance capacity (ORAC- Fluorescein) assay. J Agric Food Chem, 52: 48-54.

Fernandez-Lopez, J., Fernandez-Gines, J.M., Aleson-Carbonell, L., Sendra, E., Sayas-Barbera, E., Perez-Alvarez, J.A. (2004). Application of functional citrus by-products to meat products. Trends Food Sci Technol, 15: 176-185.

Ghasemi, K., Ghasemi, Y., Ebrahimzadeh, M.A. (2009). Antioxidant activity, phenol and flavonoid contents of 13 citrus species peels and tissues. Pak J Pharm Sci, 22: 277-281.

Gorinstein, S., Martin-Belloso, Q., Park, Y.S., Haruenkit, R., Lojek, A., Ciz, M., Trakhtenberg,
S. (2001). Comparison of some biochemical characteristics of different citrus fruits. Food Chem, 74: 309-315.

Green, C.O., Wheatley, A.O., Osagie, A.U., Morrison, E.Y.S.A., Asemota, H.N. (2007). Determination of polymethoxylated flavones in peels of selected Jamaican and Mexican citrus (Citrus spp.) cultivars by high-performance liquid chromatography. Biomed Chromatogr, 21: 48-54.

Kaul, T., Middleton, E., Ogra, P. (1985). Antiviral effects of flavonoids on human viruses. $J$ Med Virol, 15: 71-79.

Kawaii, S., Tomono, Y., Katase, E., Ogawa, K., Yano, M. (1999). HL-60 Differentiating activity and flavonoid content of the readily extractable fraction prepared from citrus juices. J Agric Food Chem, 47: 128-135.

Lario, Y., Sendra, E., Garcia-Perez, J., Fuentes, C., Sayas-Barbera, E., Fernandez-Lopez, J. (2004). Preperation of high dietary fiber powder from lemon juice by-products. Innov Food Sci Emerg Technol, 5: 113-117.

Larrauri, J.A. (1999). New approaches in the preparation of high dietary fibre powders from fruit by-products. Trends Food Sci Technol, 10: 3-8.

Lee, H.S. (2001). Characterization of carotenoids in juice of red navel orange (Cara Cara). J Agric Food Chem, 49: 2563-2568.

Li, B.B., Smith, B., Hossain, M.M. (2006). Extraction of phenolics from citrus peels I. solvent extraction method. Sep Purif Technol, 48: 182-188.

Lin, J-Y., Tang, C-Y. (2007). Determination of total phenolic and flavonoid contents in selected fruits and vegetables, as well as their stimulatory effects on mouse splenocyte proliferation. Food Chem, 101: 140-147.

Lutz, M., Hernandez, J., Henriquez, C. (2015). Phenolic content and antioxidant capacity in fresh and dry fruits and vegetables grown in Chile. CyTA-J Food, 13(4): 541-547.

Manthey, J.A., Grohmann, K. (1996). Concentration of hesperidin and other orange 
peel flavonoids in citrus processing byproducts. $J$ Agric Food Chem, 44: 811-814.

Nogata, Y., Sakamoto, K., Shiratsuchi, H., Ishii, T., Yano, M., Ohta, H. (2006). Flavonoid composition of fruit tissues of citrus species. Biosci Biotechnol Biochem, 70(1): 178-192.

Rodriguez, R., Jimenez, A., Fernandez-Bolanos, J., Guilen, R., Heredia, A. (2006). Dietary fibre from vegetable products as source of functional ingredients. Trends Food Sci Technol, 17: 3-15.

Rodriguez-Saona, L.E., Wrolstad, R.E. (2001). Acetone extraction and chloroform partition of anthocyanins. In: Current protocols in food analytical chemistry, Volume 2. John Wiley \& Sons, Inc., New York, p F1.1.1.

Ross, S.A., Ziska, D.S., Zhao, K., ElSohly, M.A. (2000). Variance of common flavonoids by brand of grapefruit juice. Fitoterapia, 71: 154-161.

Sankalpa, K.B., Ramachandra, C.T., Dinesha, B.L., Nidoni, U.K., Sharanagouda, H., Beladhadi, R.V. (2017). Effect of different drying and grinding methods on biochemical properties of sweet orange peel powder. Asian J Dairy Food Sci, 36(3): 260-263.

SAS. 2011. Base SAS 9.3 Procedures Guide. NC, USA.

Saura-Calixto, F. (1998). Antioxidant dietary fiber product: A new concept and a potential food ingredient. J Agric Food Chem, 46: 4303-4306.
Shalaby, N.M.M., Abd-Alla, H.I., Ahmed, H.H., Basoudan, N. (2011). Protective effect of Citrus sinensis and Citrus aurantifolia against osteoporosis and their phytochemical constituents. J Med Plants Res, 5: 579-588.

Sun, Y., Wang, J., Gu, S., Liu, Z., Zhang, Y., Zhang, X. (2010). Simultaneous determination of flavonoids in different parts of Citrus reticulata 'Cachi' fruit by high performance liquid chromatography - photodiode array detection. Molecules, 15: 5378-5388.

Tripoli, E., Guardia, M.L., Giammanco, S., Majo, D.D., Giammanco, M. (2007). Citrus flavonoids: Moleculer structure, biological activity and nutritional properties: A review. Food Chem, 104: 466-479.

USDA. 2013. Citrus Fruits 2013 Summary. USDA, National Agricultural Statistics Service.

Vanamala, J., Reddivari, L., Yoo, K.S., Pike, L.M., Patil, B.S. (2006). Variation in the content of bioactive flavonoids in different brands of orange and grapefruit juices. J Food Comp Analysis, 19: 157-166.

Wang, Y-C., Chuang, Y-C., Hsu, H-W. (2008). The flavonoid, carotenoid and pectin content in peels of citrus cultivated in Taiwan. Food Chem, 106: 277-284. 